\title{
Human energy metabolism below, near and above energy equilibrium
}

\author{
BY A. J. H. VAN ES, J. E. VOGT, CH. NIESSEN, J. VETH, \\ L. RODENBURG, V. TEEUWSE AND J. DHUYVETTER \\ Department of Animal Physiology, Agricultural University, Haarweg 10, \\ 6709 PJ Wageningen, The Netherlands \\ AND P. DEURENBERG AND J. G. A. J. HAUTVAST \\ Department of Human Nutrition, Agricultural University, De Dreijen 12, \\ 6703 BC Wageningen, The Netherlands \\ AND E. VAN DER BEEK \\ Central Institute for Nutrition and Food Research (TNO), P.O. Box 360, \\ 3700 AJ Zeist, The Netherlands
}

(Received 7 February 1984 - Accepted 22 March 1984)

\begin{abstract}
1. Complete $24 \mathrm{~h}$ energy and nitrogen balances were measured for fifteen subjects at three levels of energy intake and for two other subjects at two levels of intake.

2. At each level, the fifteen subjects ate diets consisting of fifteen to twenty separate foods for 7 or $8 \mathrm{~d}$. Faeces and urine were collected for the final $4 \mathrm{~d}$. Respiratory gas exchange was measured during the final $72 \mathrm{~h}$ while the subjects stayed in an $11 \mathrm{~m}^{3}$ open-circuit respiration chamber, and simulated office or light household work. The energy balance of the other two subjects was determined initially in a similar way when they consumed a diet which was sufficient for energy equilibrium. Subsequently, the measurements were repeated twice at the same high level of metabolizable energy (ME) intake after 4 and $18 \mathrm{~d}$ on that diet.

3. Neither energy nor $\mathrm{N}$ digestibilities were significantly affected by intake level or subject. Due to relatively small urinary energy losses the ME content of the gross energy increased slightly at the higher intake.

4. Respiratory quotient increased with intake level from 0.78 to 0.87 .

5. The efficiencies of utilization of $\mathrm{ME}$ were approximately 1.0 for maintenance (from the low to the intermediate intake level) and decreased to about 0.9 for maintenance and energy deposition (from the intermediate to the high intake level).

6. Estimates of daily ME requirements at energy equilibrium were 149 (SD 13) $\mathrm{kJ} \mathrm{ME} / \mathrm{kg}$ body-weight, 432 (SD 33) $\mathrm{kJ} \mathrm{ME} / \mathrm{kg}$ body-weight ${ }^{\circ \cdot 75}$ and 204 (SD 22) $\mathrm{kJ} / \mathrm{kg}$ lean body mass. The former two values were negatively correlated with percentage body fat although not significantly so.

7. ME utilization and heat production of the other two subjects were nearly equal after 6 and $20 \mathrm{~d}$ on a diet supplying 1.5-1.7 times the ME needed for energy equilibrium.
\end{abstract}

Information on the amount of metabolizable energy (ME) required at energy equilibrium of individuals performing office or light household work is scarce. The same is true for our knowledge of the efficiency of utilization of ME when ingested in amounts smaller or greater than needed for energy equilibrium. Energy balance measurements are well suited to provide such information. However, the number of such measurements lasting $24 \mathrm{~h}$ or more is small (Apfelbaum et al. 1971; Agricultural Research Council/Medical Research Council Committees, 1974; Dauncey, 1979, 1980; Irsigler et al. 1979; Webb, 1981; Ravussin et al. 1982; Schutz et al. 1982). In some of these studies intake of ME was not measured but calculated, the calorimetric rooms used for measurements were small, having a volume of only $5 \mathrm{~m}^{3}$, and room temperatures were sometimes high (see Table 7, p. 440).

The aim of the present study was to obtain more reliable information on $24 \mathrm{~h}$ energy metabolism of human adults performing office or light household work during the day and consuming the same diet. The study consisted of three series of experiments (Table 1). In 
Table 1. Experimental scheme

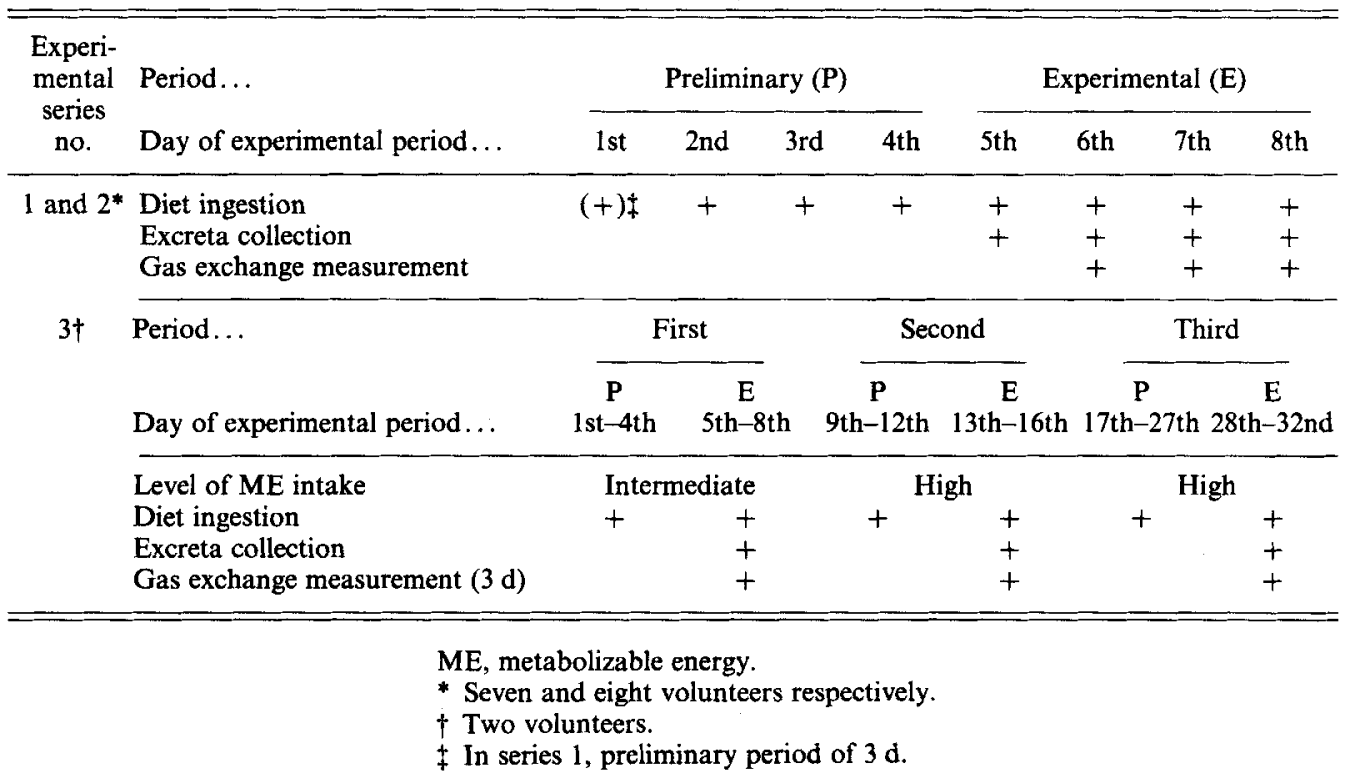

the first series of experiments, energy and nitrogen balances (during days 5-8 on the diet) for seven volunteers were measured far below, slightly below and above energy equilibrium. The second series of experiments was a duplication of the first series with eight other volunteers. It was expected that these two series of experiments would provide information on utilization of ME and on diet-induced thermogenesis. Furthermore, the experiments would provide information on the variation in $24 \mathrm{~h}$ requirements between subjects. In the third series of experiments the energy balances of two volunteers were measured three times, first for $3 \mathrm{~d}$ at approximately energy equilibrium after $4 \mathrm{~d}$ on the diet, and then after 4 and after $18 \mathrm{~d}$ while on a diet supplying 1.5-1.7 times the ME consumed daily in the first week. This third series of experiments was an attempt to test the theory of Garrow (1978) that utilization of ME might change during the course of long periods of high ME intake, which was also discussed by Hervey \& Tobin (1983).

\section{MATERIALS AND METHODS}

Subjects

Seventeen volunteers (eight females, nine males) aged 18-64 years took part. Before the experiments they were made familiar with experimental procedures and respiration chambers. All were, according to medical examination, in good health. Their body-weights, heights and skinfold thicknesses were measured (Durnin \& Womersley, 1974). Specific density was also determined by underwater weighing with correction for lung volume for the subjects of the second and third series of experiments (Table 6, p. 438). While in the respiration chambers, subjects weighed themselves twice daily. None of the subjects smoked tobacco. 


\section{Diets}

The diets were formulated so that they were not very different from a habitual diet but still could be analysed without difficulties. They consisted of fifteen to twenty foods, each weighed in daily portions and sampled, providing breakfast, lunch and dinner (to be heated in hot water) as well as milk, coffee, juice, etc. Some volunteers of experimental series 1 preferred a vegetarian diet, so in their diets meat and meat products were replaced by cheese and margarine.

The approximate energy composition of the diet was; $42 \%$ from fat, $13 \%$ from protein, $45 \%$ from carbohydrate. Thus, the composition of the diet and foods it contained reflected an average diet in The Netherlands. Bread, margarine and minced meat contributed most to the energy of the non-vegetarian diets in experimental series 1 and 2; bread, cheese, minced meat, milk and yoghurt contributed most to the dietary N. For the vegetarian diets the corresponding items were bread, margarine and cheese, and bread, cheese, milk and yoghurt respectively.

In principle the diets at each of the three levels of energy intake of experimental series 1 and 2 were of similar composition except that the same daily quantity of vegetables was used at all levels to supply adequate 'bulk'. In experimental series 3 at the high level of intake, in addition to increasing the quantities of several food items, some foods were included which the subjects liked.

A rough estimate of the subjects' usual ME intake at home was obtained by a $3 \mathrm{~d}$ weighed dietary record, including one weekend day. Total ME intake was estimated by using The Netherlands Foodtables (1981). These estimates and an enquiry on the subjects' physical activity formed the basis of their diet at the intermediate level of intake. At the low and high intake levels, 0.5 and 1.5 times as much was ingested respectively. The intermediate diet was set rather low to ensure that the volunteers would be able to consume the high-intake diet completely.

For most ingredients daily portions were weighed for an entire experimental series at a time. These portions were packed in plastic bags or boxes and stored, if necessary, at low temperature. Daily portions of beverages and margarine were weighed for a 2-3 d period $1 \mathrm{~d}$ before the preliminary period and before and during the main period. Items which might deteriorate during long cold storage were weighed only for two to four experiments at a time. Duplicate samples were taken from each portion just before weighing. For homogeneous items like milk, yoghurt and apple juice usually only one sample was taken. The vegetables and the minced meat were cooked before sampling and weighing of daily portions.

\section{Excreta}

Total collection of faeces and urine (Table 1) was made during the last $4 \mathrm{~d}$ of each experiment after the diet had been eaten for 3 (experimental series 1), 4 (experimental series 2 and first two experiments of series 3) or $18 \mathrm{~d}$ (last experiment of series 3). Excreta were collected several times daily and stored in a refrigerator.

\section{Measurement of respiratory gas exchange}

Two open-circuit respiration chambers of $11 \mathrm{~m}^{3}$, formerly used for farm animals (Van Es, 1966; Verstegen, 1971), were converted into hotel rooms and equipped with a bed, chair, bicycle home-trainer, wash-stand/writing desk, radio, television set and telephone. Two small airlocks served for the supply of food and removal of excreta. The volume of the air drawn from each chamber was measured by a small dry gas meter. Samples of in- and outgoing air were collected in glass tubes over mercury (composite sample) as well as analysed continuously by a paramagnetic oxygen analyser and an infrared carbon dioxide 
analyser. The $24 \mathrm{~h}$ composite samples were analysed volumetrically with a Sonden apparatus. The results of the physical gas analyses served to study variations in gas exchange during the $24 \mathrm{~h}$. Heat production was calculated by Brouwer's (1965) equation from $\mathrm{O}_{2}$ consumption, $\mathrm{CO}_{2}$ production and urinary $\mathrm{N}$ excretion. The composite samples were occasionally analysed also by the infrared analyser or with the Sonden apparatus for methane. At the start and end of each $24 \mathrm{~h}$ experiment, samples of chamber air were taken and analysed. The equipment was checked by introducing known quantities of $\mathrm{CO}_{2}$ into the chambers. Recovery was 99 (SD $1 \cdot 5$ ) \% . Moreover, the $\mathrm{O}_{2}$ analysis was checked by analysis of fresh outdoor air during each $24 \mathrm{~h}$ experiment.

Chamber temperatures were 21 or $22^{\circ}$ (depending on the volunteers' wish) from 07.30 to 22.30 hours and $2^{\circ}$ lower during the night. Relative humidity was kept at about $70 \%$.

Subjects went to bed at approximately 23.00 hours and rose between 07.30 and 08.00 hours. They ate breakfast, lunch and dinner at about 08.30, 12.30 and 18.00 hours respectively and cycled for approximately $15 \mathrm{~min}$ at moderate speed on the home-trainer at 08.30 or $08.45,12.00$ or $12.15,13.15$ or $13.30,17.30$ and 22.30 hours. They were otherwise free to do what they liked except physical exercise, other than moving occasionally from chair to desk, etc.

\section{Analyses}

$\mathrm{N}$ in foods and excreta was determined by the Kjeldahl method using mercury as a catalyst (International Organization for Standardization, 1979).

Energy was determined using a static bomb calorimeter. Wet samples were dried first, either by freeze-drying (vegetables, faeces), at room temperature in vacuo (fluids; dried in a polyethylene bag and after drying combusted with the bag) or at $70^{\circ}$ in a forced-air drying oven. Samples of cheese, minced meat, sausages and saveloy were mixed with silica gel powder, homogenized and weighed in polyethylene bags. Samples of margarine were also weighed in such bags. Bags with contents were combusted.

All analyses were done at least in duplicate on each sample.

\section{Statistical analysis}

Variation in results between subjects was shown by standard deviations. Student's $t$ test, usually for paired observations, was used to see if differences were significant.

\section{Ethics}

The study was approved by the Ethical Committee of the Department of Human Nutrition of the Agricultural University.

\section{RESULTS}

\section{Diets}

All dietary items were eaten completely. The coefficients of variation due to sampling and analytical error of the values for energy and $\mathrm{N}$ contents used in subsequent calculations (averages of at least duplicate analyses, usually in two samples) were seldom above $1 \%$. Variation in energy and $\mathrm{N}$ contents of different batches of some items (minced meat, cheese, milk, yoghurt, sausage) was greater (up to $3 \%$ ), so it was necessary to sample and analyse the foods of each new batch, certainly for the items mentioned and preferably for all.

\section{Energy and $N$ losses in faeces and urine}

Table 2 shows the composition of faeces, digestibilities of energy and $\mathrm{N}$ and energy losses in the urine at the three levels of ME intake. The composition of faecal dry matter was fairly constant. 
Human energy metabolism

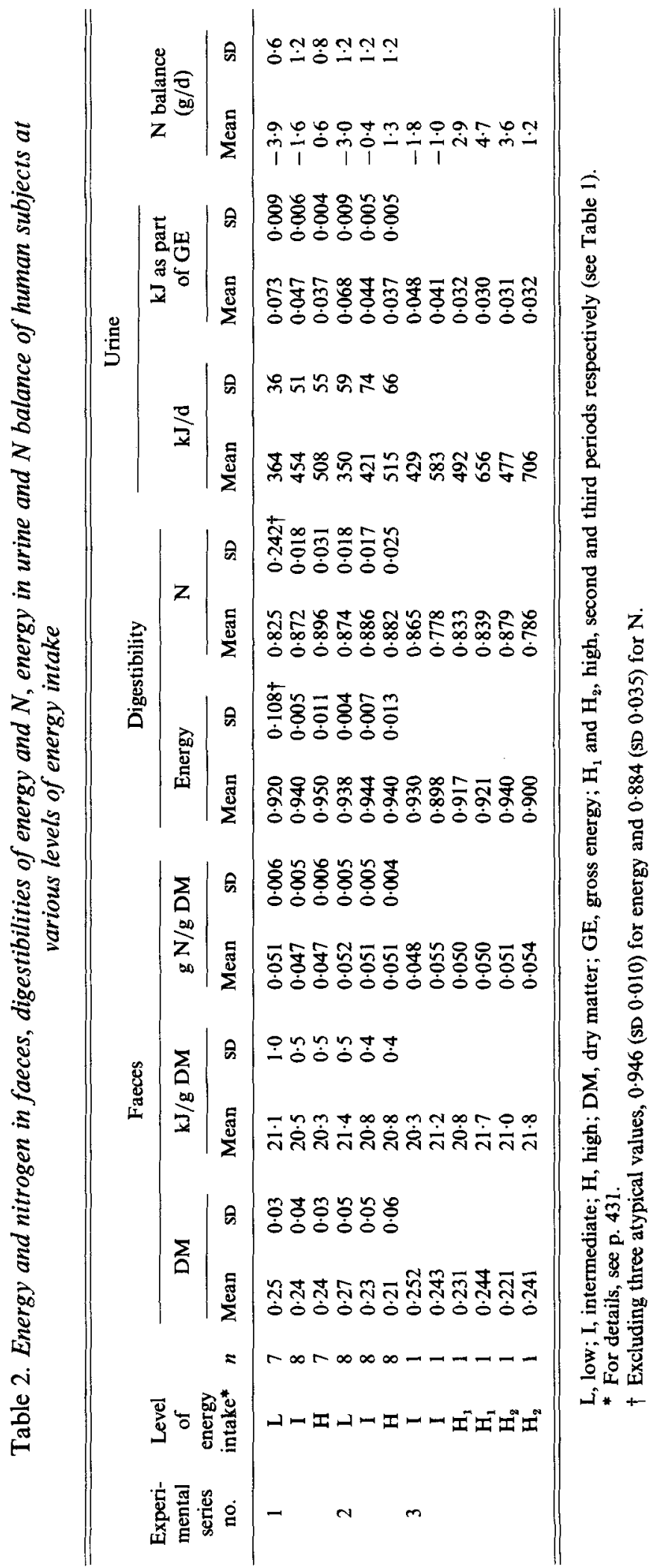


Irregular defaecation of three of the subjects at the low intake level in experimental series 1 increased the variation of digestibility (see footnote of Table 2). In further calculations their digestibility values were replaced by the average energy and $\mathrm{N}$ digestibilities, excluding the extremes, i.e. 0.946 and 0.884 respectively, because the actual values were considered to be due to a short collection period and not to a low digestibility of the diet.

In both experimental series 1 and 2, intake level had no significant effect on the digestibilities of energy and $\mathrm{N}$; also there was no significant variation between subjects.

In the urine, energy content was strongly correlated with $\mathrm{N}$ content $(P<0.01)$. At the low and intermediate energy intakes, $\mathbf{N}$ balances (ingested $\mathrm{N}$ minus $\mathrm{N}$ in faeces and urine) were negative (Table 2). At the high-intake level some $\mathrm{N}$ was retained. This and the high correlation between the $\mathrm{N}$ and energy contents of the diets explains why urinary energy losses as a percentage of gross energy (GE) decreased with the higher intake; in absolute terms they increased (Table 2). Since ME is GE minus energy in faeces and urine, the ME content of the ingested energy (ME/GE, Table 3) increased with the higher intake level despite approximately constant energy digestibility.

\section{Combustible gases}

Methane production due to microbial conversions in the large intestine was very low or below the detection level. The highest quantity measured in experimental series 1 and 2 was 1 litre $/ 24 \mathrm{~h}$, about $40 \mathrm{~kJ}$. Some subjects tended to produce hardly any methane. In further calculations energy losses from methane were neglected.

\section{$N$ balances}

In view of the short-term nature of the experimental periods, $\mathrm{N}$ balances were considered to have low precision. Moreover, at the low and high intake levels of experimental series 1 and 2 and in the second experiment of series 3, they might not have stabilized because of the short preliminary period. For these reasons no further attention will be paid to these balances.

\section{Respiratory gas exchange and calculated heat production}

Respiratory quotients (Table 3) were less than 1 and increased with intake level. The diets' fat content as well as the negative energy balance at the low energy intake, and often at the intermediate level too (Table 3), were clearly responsible for the low values. At the high intake, fat deposition caused a further increase.

Daily heat production, calculated from $\mathrm{O}_{2}$ consumption, $\mathrm{CO}_{2}$ production and urinary $\mathrm{N}$, had an average coefficient of variation $(\%)$ of 2.8 (SD 1.4) in experimental series 1 , and 2.2 (SD 1.5) in experimental series 2 for the same subjects in their $3 \mathrm{~d}$ gas exchange measurement. Usually, despite the overnight stay in the chamber before the start of the measurement, subjects tended to have a 1-3\% higher heat production during the 1 st day of the three consecutive measurements than during the 2 nd and $3 \mathrm{rd}$ days. The highest 1 st-day value was found for subjects for whom the chamber and its surroundings were known only from a few short visits before the experiments. Because differences were small, average values of heat production of all $3 \mathrm{~d}$ of one experiment were used in further calculations.

Within subjects heat production at the intermediate level of intake was only 0.2 (SE 0.05$)$ $\mathrm{MJ} / \mathrm{d}$ higher than at the low level $(P<0.01)$. This is obviously a consequence of mobilization and utilization of energy of the body reserves at the lower intake with a similar efficiency of utilization for maintenance purposes as for the diet. According to energy and $\mathrm{N}$ balances, about $90 \%$ of the mobilized tissue energy consisted of energy in fat and about $10 \%$ in protein. Half the diets' energy consisted also of fat and protein, the other half was mostly carbohydrate. Utilization of carbohydrate energy for maintenance purposes is slightly more efficient than that of fat energy because of the greater potential of carbohydrate 


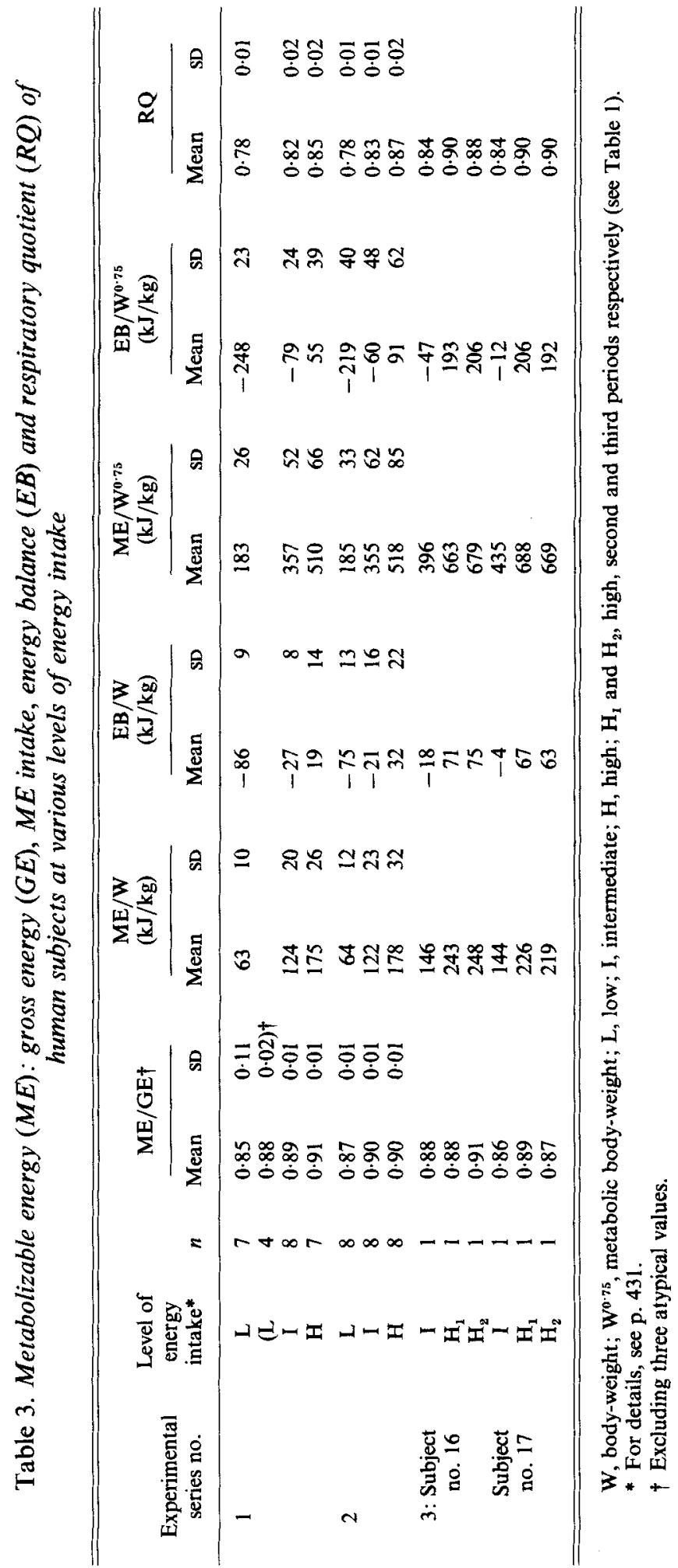


energy for ATP production. The diets, however, had to be digested, the reserves only to be mobilized, so the more efficient utilization of the carbohydrates may have been counteracted by the costs of digestion.

Heat production at the high intake was, within subjects, 0.6 (SD 0.03) MJ more than at the intermediate level $(P<0.01)$. Obviously utilization of the ME of the diet for maintenance and fat deposition was slightly less efficient than for maintenance only, probably due to the costs of conversion of dietary carbohydrate and protein to body fat.

In experimental series 3, heat production increased by 5 and $7 \%$ after the change from the intermediate to the high intake level and remained at that level during the next weeks on that level of intake.

\section{Energy balances and $M E$ requirements at energetic equilibrium}

Energy balances (EB) were calculated by subtracting heat production from ME intake. Positive EB were found only at the high level of energy intake (Table 3). For better comparison both ME and EB values were divided by either body-weight (W, $\mathrm{kg}$ ) or metabolic weight $\left(\mathrm{W}^{0.75}, \mathrm{~kg}\right)$. Values of the efficiency of the utilization of ME for maintenance $\left(k_{m}\right)$ and for a mixture of maintenance and fat deposition $\left(k_{m f}\right)$ were computed from the three or four results of each subject by dividing the difference in EB by the difference in $M E$ intake between the low and intermediate and the intermediate and high intake levels respectively (e.g., $k_{m}=(\Delta \mathrm{EB} / \mathrm{W}) /(\Delta \mathrm{ME} / \mathrm{W})$ for the low and intermediate intake levels; $k_{m f}=(\Delta \mathrm{EB} / \mathrm{W}) /(\Delta \mathrm{ME} / \mathrm{W})$ for the intermediate and high levels (Table 4$\left.)\right)$.

The resulting values for $k$ were used in various ways to estimate the ME requirement at energetic equilibrium $\left(\mathrm{ME}_{\mathrm{m}}\right)$ of the subjects of experimental series 1 and 2 . The values $\mathrm{ME} / \mathrm{W}$ or $\mathrm{ME} / \mathrm{W}^{0.75}$ of experiments with $\mathrm{EB}$ values closest to zero for each subject were corrected to values applying to zero balances by subtracting $(1 / k) \times(\mathrm{EB} / \mathrm{W})$ or $(1 / k) \times\left(\mathrm{EB} / \mathrm{W}^{0 \cdot 75}\right)$. The value of $k$ used was either the value of $k_{m}$ or $k_{m f}$ calculated for each subject or the average value of $k_{m}$ or $k_{m f}$ for all subjects of the same experimental series. Furthermore, a third estimate of $\mathrm{ME}_{\mathrm{m}}$ was obtained from the regression, for each subject, $\mathrm{EB} / \mathrm{W}$ or $\mathrm{EB} / \mathrm{W}^{0.75} v . \mathrm{ME} / \mathrm{W}$ or $\mathrm{ME} / \mathrm{W}^{0.75}$ and calculating the values of $\mathrm{ME} / \mathrm{W}$ or $\mathrm{ME} / \mathrm{W}^{0.75}$ for $\mathrm{EB} / \mathrm{W}$ or $\mathrm{EB} / \mathrm{W}^{0.75}$ equal to zero from the regression equation.

The calculated values of $k_{m}$ and $k_{m f}$ were, for experimental series 1, 1.02 (SE 0.05 ) and 0.85 (SE 0.02) respectively and, for experimental series $2,0.92$ (SE 0.08 ) and 0.94 (SE 0.03 ) respectively; for experimental series 3 the values of $k_{m f}$ were 0.90 and 0.87 for subject nos. 16 and 17 respectively. The difference between $k_{m}$ and $k_{m f}$ of experimental series 1 was significant $(P<0.01)$. The high standard deviation of $k_{m}$ in experimental series 2 was probably caused by two subjects who during their experiment at the intermediate intake level showed a high heat production. They were not familiar with the department and it was the first of their three experiments, so they may have had an elevated heat production due to stress. Without their values the estimates of $k_{m}$ and $k_{m f}$ in experimental series 2 were 1.03 (SE 0.03 ) and 0.91 (SE 0.02 ) respectively, values which differed significantly $(P<0.01$ ).

The values of maintenance $M E$ requirements $(\mathrm{kJ} / \mathrm{kg}) \mathrm{ME}_{\mathrm{m}} / \mathrm{W}, \mathrm{ME}_{\mathrm{m}} / \mathrm{W}^{0.75}$ and $\mathrm{ME}_{\mathrm{m}} /$ lean body mass (LBM), calculated by using the subject's own or the average value for $k$, or the regression method, hardly differed (Table 5). Using the maintenance requirements obtained by regression for all subjects of experimental series 1 and 2 , mean values for men and women were separately calculated and were found to be significantly different $(P<0.01)$ only when expressed as $\mathrm{ME}_{\mathrm{m}} / \mathrm{LBM}$ (Table 5).

The maintenance requirements per $\mathrm{W}$ or $\mathrm{W}^{0 \cdot 75}$ were also correlated with body fat content $(r-0.45$ and -0.53 respectively), with age $(r-0.41$ and -0.28 respectively) and with height $(r-0.21$ and -0.03 respectively). Only the correlation with body fat percentage approached significance at the $5 \%$ level. 


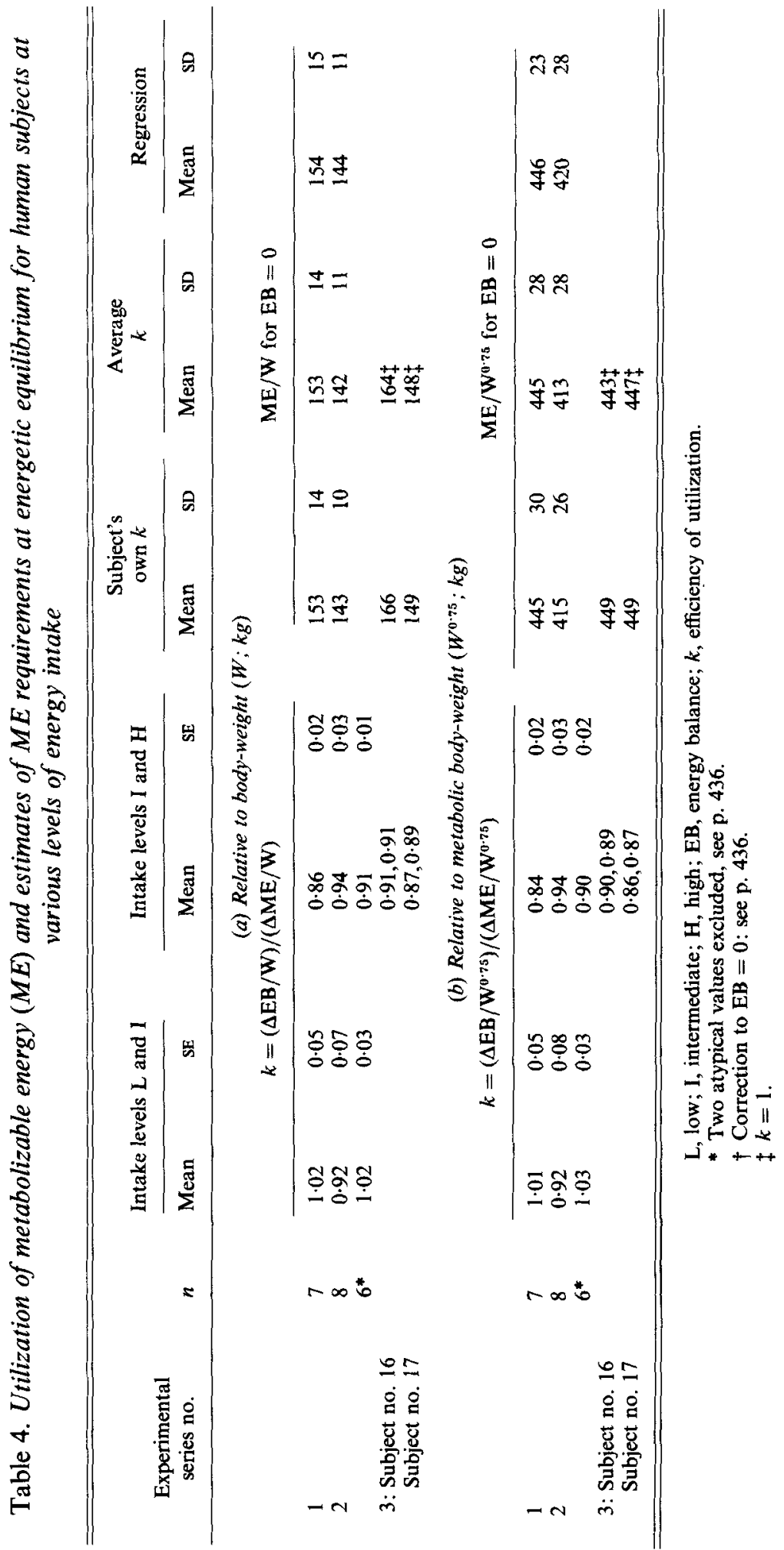


Table 5. Estimates of metabolizable energy $(M E)$ requirements at energetic equilibrium for human subjects (experimental series 1 and 2)

(Mean values and their standard deviations)

\begin{tabular}{|c|c|c|c|c|c|c|c|c|c|c|}
\hline \multirow{2}{*}{$\begin{array}{c}\mathrm{ME} \text { for } \\
\text { maintenance } \\
\left(\mathrm{ME}_{\mathrm{m}}\right) \\
(\mathrm{kJ} / \mathrm{kg})\end{array}$} & \multicolumn{2}{|c|}{$\begin{array}{l}\text { Subject's } \\
\text { own } k\end{array}$} & \multicolumn{2}{|c|}{$\begin{array}{c}\text { Average } \\
k\end{array}$} & \multicolumn{2}{|c|}{ Regression } & \multicolumn{2}{|c|}{$\delta(n 8)$} & \multicolumn{2}{|c|}{$q(n 7)$} \\
\hline & Mean & SD & Mean & SD & Mean & SD & Mean & $\mathrm{SD}$ & Mean & SD \\
\hline $\mathrm{ME}_{m} / \mathrm{W}$ & 148 & 13 & 147 & 13 & 149 & 13 & 150 & 14 & 147 & 14 \\
\hline $\mathrm{ME}_{\mathrm{m}} / \mathrm{W}^{0 \cdot 75}$ & 429 & 31 & 428 & 32 & 432 & 33 & 442 & 31 & 421 & 33 \\
\hline $\mathbf{M E}_{\mathrm{m}} / \mathrm{LBM}$ & 203 & 22 & 202 & 22 & 204 & 22 & 190 & 13 & $220^{* *}$ & 19 \\
\hline
\end{tabular}

W, body-weight; $\mathbf{W}^{0 \cdot 75}$, metabolic W; LBM, lean body mass.

Significantly different from value for $\mathrm{ME}_{\mathrm{m}} / \mathrm{LBM}$ for $\delta^{*}: * * P<0.01$.

Table 6. Details of subjects and estimates of their maintenance requirements for metabolizable energy $(M E)$ expressed on a body-weight $(W)$ and metabolic body-weight $\left(W^{0.75}\right)$ basis

\begin{tabular}{|c|c|c|c|c|c|c|c|c|c|}
\hline \multirow[b]{2}{*}{$\begin{array}{l}\text { Experimental } \\
\text { series no. }\end{array}$} & \multirow[b]{2}{*}{$\begin{array}{l}\text { Subject } \\
\text { no. }\end{array}$} & \multirow[b]{2}{*}{$\begin{array}{r}\text { Wt } \\
(\mathrm{kg})\end{array}$} & \multirow[b]{2}{*}{$\begin{array}{l}\text { Height } \\
\text { (m) }\end{array}$} & \multicolumn{2}{|c|}{ Body fat $(\mathrm{g} / \mathrm{kg})$} & \multirow[b]{2}{*}{$\begin{array}{c}\text { Age } \\
\text { (years) }\end{array}$} & \multirow[b]{2}{*}{ Sex } & \multicolumn{2}{|c|}{$\begin{array}{r}\text { Maintenance } \\
\text { requirement }\end{array}$} \\
\hline & & & & $\begin{array}{l}\text { From } \\
\text { skin- } \\
\text { folds }\end{array}$ & $\begin{array}{l}\text { From } \\
\text { specific } \\
\text { density }\end{array}$ & & & $\begin{array}{l}\mathrm{ME} / \mathrm{W} \\
(\mathrm{kJ} / \mathrm{kg})\end{array}$ & $\begin{array}{c}\mathrm{ME} / \mathrm{W}^{0.75} \\
(\mathrm{~kJ} / \mathrm{kg})\end{array}$ \\
\hline \multirow[t]{8}{*}{1} & 1 & 68 & 1.81 & 180 & - & 28 & $\sigma^{*}$ & $170^{*}$ & $490^{*}$ \\
\hline & 2 & 62 & 1.63 & 300 & - & 22 & $q$ & 165 & 464 \\
\hline & 3 & 85 & 1.84 & 300 & - & 53 & $\sigma^{*}$ & 133 & 405 \\
\hline & 4 & 67 & 1.78 & 160 & - & 22 & 0 & 159 & 456 \\
\hline & 5 & 75 & 1.75 & 380 & - & 19 & q & 137 & 404 \\
\hline & 6 & 63 & 1.70 & 300 & 一 & 19 & 우 & 167 & 474 \\
\hline & 7 & 79 & 1.82 & 200 & - & 55 & $\sigma^{t}$ & 144 & 431 \\
\hline & Mean (SD) & $71(9)$ & $1 \cdot 76(7)$ & $260(80)$ & & $31(16)$ & & $154(15)$ & $446(34)$ \\
\hline \multirow[t]{9}{*}{2} & 8 & 69 & 1.75 & 200 & 150 & 41 & a & 163 & 472 \\
\hline & 9 & 76 & 1.67 & 400 & 420 & 61 & 우 & 133 & 393 \\
\hline & 10 & 74 & 1.64 & 400 & 420 & 64 & 오 & 139 & 407 \\
\hline & 11 & 56 & 1.71 & 270 & 230 & 24 & $q$ & 147 & 403 \\
\hline & 12 & 84 & 1.91 & 220 & 200 & 31 & $\sigma^{*}$ & 132 & 400 \\
\hline & 13 & 69 & 1.74 & $(250) \dagger$ & 230 & 24 & $q$ & 140 & 405 \\
\hline & 14 & 77 & 1.81 & $(200) \dagger$ & 180 & 53 & $\pi$ & 145 & 430 \\
\hline & 15 & 73 & 1.80 & 220 & 220 & 57 & 3 & 155 & 453 \\
\hline & Mean (SD) & $72(8)$ & $1.75(9)$ & $270(80)$ & & 44 (17) & & $144(11)$ & $420(28)$ \\
\hline \multirow[t]{2}{*}{3} & 16 & 53 & 1.66 & - & 200 & 23 & $q$ & $164 \ddagger$ & $443 \ddagger$ \\
\hline & 17 & 84 & 1.81 & - & 130 & 25 & $\sigma^{*}$ & $148 \ddagger$ & $447 \ddagger$ \\
\hline
\end{tabular}

* Obtained by the regression method.

$\uparrow$ Estimated from density; skinfold value not measured.

$\ddagger$ Energy utilization $(k)=1$.

The maintenance requirements of subjects nos. 16 and 17 of experimental series 3 derived from their measurement at the intermediate level using a $k_{m}$ of 1.0 were $(\mathrm{kJ} / \mathrm{kg}) 164$ and $148 \mathrm{ME} / \mathrm{W}, 443$ and $447 \mathrm{ME} / \mathrm{W}^{0 \cdot 75}$, and 205 and $170 \mathrm{ME} / \mathrm{LBM}$ respectively.

Table 6 shows details of the subjects and their estimated maintenance requirements; in Fig. 1 the values $M E / W^{0.75}$ are plotted against the values $E B / W^{0.75}$ for all seventeen subjects. 


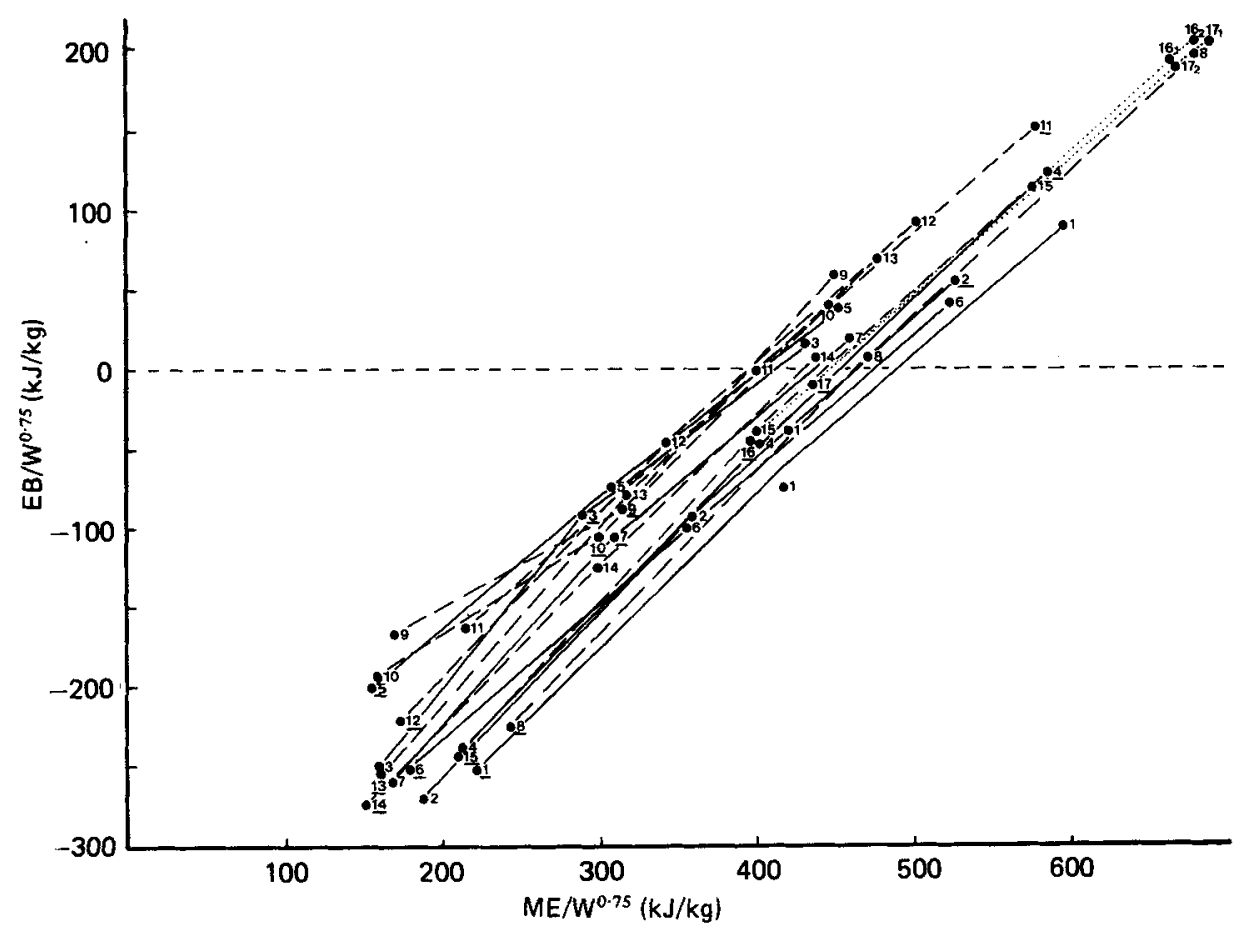

Fig. 1. Energy balance (EB/body weight $(W)^{0.75}$ ) in relation to metabolizable energy (ME) intake $\left(\mathrm{ME} / \mathrm{W}^{0^{\bullet 5}}\right)$. Results are for experiments with the same subjects in experimental series $1(-), 2(--)$ and $3(\cdots)$. The numbers given refer to the subject's experimental number; numbers which are underlined indicate the first experiment with the subject.

\section{DISCUSSION}

The absence of significant differences in digestibility between healthy subjects and at various levels of energy intake is in agreement with similar results obtained with simple stomached animals (Schürch, 1969). Because of the high digestibility of the diets even a collection period of only $4 \mathrm{~d}$ provides a sufficient precision of the measured digestibility coefficient, except at low intake levels because of irregular defaecation. The slight increase in the ME content of the diet with increasing level of energy intake was clearly a consequence of the fact that $\mathbf{N}$ and energy balances responded similarly to increased food intake in these short-term studies. It is probable that in long-term studies, $\mathbf{N}$ balances at both low and high energy intake levels would be closer to zero, which would reduce the effect of intake level on ME content.

The values for the efficiency of the utilization of the ME for maintenance and fat deposition, $k_{m f}$, were high, as would be expected for a highly-digestible diet containing much fat. The results of experimental series 3 show that during a period of 3 weeks of high-energy intake the efficiency does not decrease. The high efficiency values mean that food ingested in excess of requirement is largely converted into body tissue, mainly fat. Low supply of food results in an even more efficient utilization of mobilized tissue energy, again mainly fat. The high energy content of fat, together with man's fairly low requirement of ME for maintenance, equivalent to the energy of about $200 \mathrm{~g}$ fat, explains why only prolonged high or low intake levels result in clear body-weight changes.

The fact that several subjects had a higher heat production during their 1st day in the 


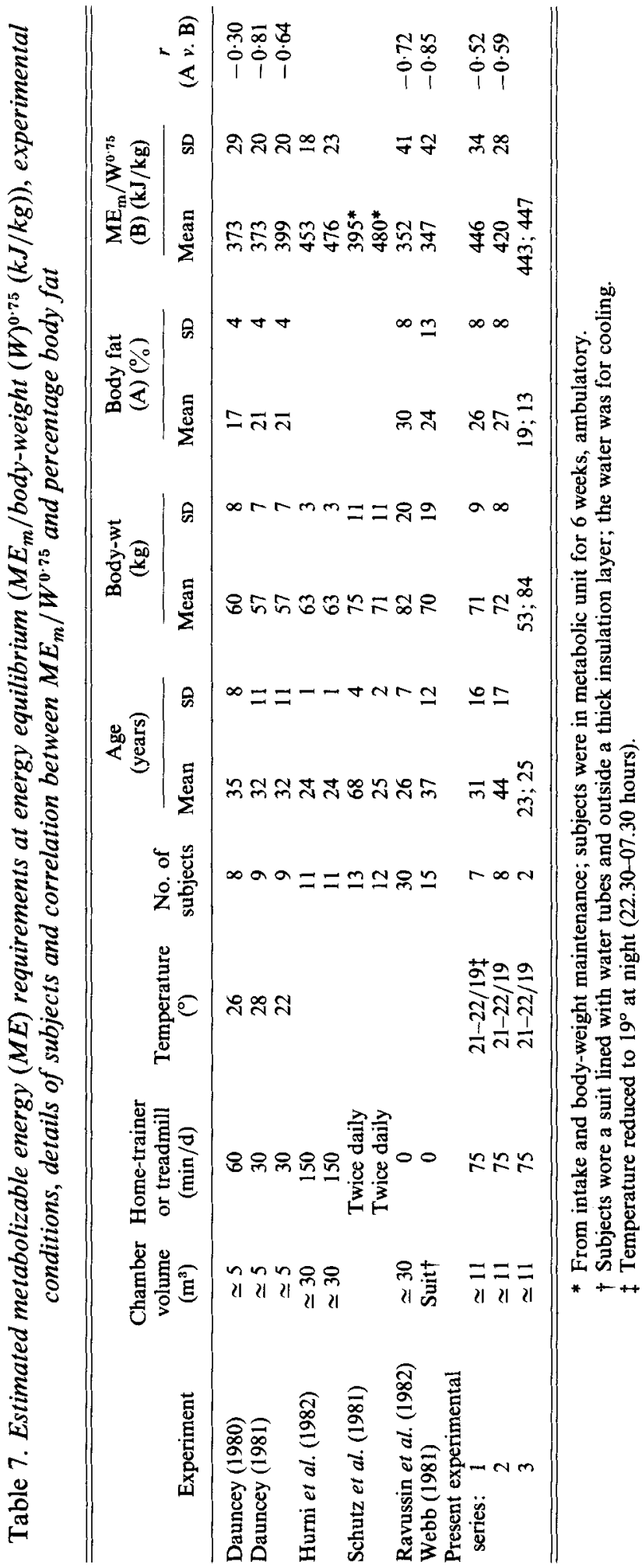


respiration chamber, even after an overnight stay, and that some of the first of the three experiments tended to give somewhat low energy balances (see Fig. 1) suggest avoidance of short periods of measurement.

The average energy requirements found appear to be higher than those found in other studies (Table 7). It is difficult to compare the various results. Techniques differ and are sometimes not clearly described. In some studies energy balances were not measured, so estimates of $\mathrm{ME}_{\mathrm{m}} / \mathrm{W}^{0.75}$ were derived by us from heat productions measured while the subjects were assumed to be close to energy equilibrium. The higher level of physical exercise, activity while preparing meals, etc. and the lower temperature in the present experiments may have led to the higher values.

Most studies show a lower maintenance requirements per $\mathrm{W}$ or $\mathrm{W}^{0.75}$ with higher percentage body fat. This might be due to the lower metabolic activity of fat tissue compared with lean tissue. An unbiased interpretation of the results is complicated by the fact that age and percentage body fat are often positively correlated and that obese subjects usually are physically less active than lean subjects.

The coefficients of variation of the ME requirements of the subjects at energetic equilibrium under the circumstances of the present experiment were 9 and $8 \%$ when expressed per $W$ and per $W^{0.75}$ respectively. Part of this variation was due to analytical errors which might be estimated to cause a variation of about $5 \%$. This leaves a coefficient of about $7 \%$ for variation between subjects per se, a fairly low value in view of the considerable variation in age, height, weight and body composition of the subjects. A similar size of variation has been found in cattle (Agricultural Research Council, 1980). One might have expected a greater variation in man because of the absence of the influence of selection. However, a variation of $7 \%$ suggests that some subjects have a $10-15 \%$ lower or higher requirement for energy than the average.

The present investigation was supported by The Netherlands Heart Foundation. The authors wish to thank Miss C. A. Roovers, Mr W. A. van Kranenburg and Mr M. J. N. Los for their careful assistance in preparing meals, care for the experimental subjects and analytical work. The authors also thank the volunteers for their enthusiastic co-operation and the Akademie Diedenoort at Wageningen for preparation of food.

\section{REFEREN CES}

Agricultural Research Council (1980). Nutrient Requirements of Ruminant Livestock, pp. 73-82. London: H.M. Stationery Office.

Agricultural Research Council/Medical Research Council Committees (1974). Food and Nutrition Research, pp. 31-34, 108-110. Amsterdam: Elsevier.

Apfelbaum, N., Bostsarron, J. \& Lacatis, D. (1971). American Journal of Clinical Nutrition 24, $1405-1409$.

Brouwer, E. (1965). Proceedings 3rd Symposium on Energy Metabolism, pp. 441-443. EAAP Publication no. 11.

Dauncey, M. J. (1979). Journal of Human Nutrition 33, 259-269.

Dauncey, M. J. (1980). British Journal of Nutrition 43, 257-269.

Dauncey, M. J. (1981). British Journal of Nutrition 45, 257-267.

Durnin, J. V. G. A. \& Womersley, J. (1974). British Journal of Nutrition 32, 77-97.

Garrow, J. S. (1978). Recent Advances in Obesity Research, vol. 2, pp. 200-210 [G. A. Bray, editor]. Washington, DC: Newman.

Hervey, G. R. \& Tobin, G. (1983). Clinical Science 64, 7-18.

Hurni, M., Burnand, B., Pittet, Ph. \& Jéquier, E. (1982). British Journal of Nutrition 47, 33-43.

International Organization for Standardization (1979). International Standard no. 5983.

Irsigler, K., Veitl, V., Sigmund, A., Tschegg, E. \& Kunz, K. (1979). Metabolism 28, 1127-1132.

Ravussin, E., Burnand, B., Schutz, Y. \& Jéquier, E. (1982). American Journal of Clinical Nutrition 35, 566-573.

Schürch, A. (1969). In Handbuch der Tierernährung, vol. 1. p. 280 [W. Lenkeit, K. Breirem and E. Crasemann, editors]. Hamburg: Parey.

Schutz, Y., Calloway, D. H., Butterfield, G. \& Margen, S. (1981). International Journal for Vitamin and Nutrition Research 51, 194-195. 
Schutz, Y., Ravussin, E., Diethelm, R. \& Jéquier, E. (1982). International Journal of Obesity 6, 23-28.

The Netherland Foodtables (1981). Nederlandse Voedingsmiddelen Tabel. 33rd ed. Den Haag: Voorlichtingsbureau voor de Voeding.

van Es, A. J. H. (1966). Netherland Journal of Agricultural Science 14, 32-46.

Verstegen, M. W. A. (1971). Communications of the Agricultural University of Wageningen 71-2, 20-22.

Webb. P. (1981). American Journal of Clinical Nutrition 34, 1816-1826. 